\title{
Moderate Hypothermia Has the Potential to Reveal the Dominant/Submissive Relationship in a Co-Culture System Consisting of Osteoblasts and Endothelial Cells
}

\author{
Kouki Inomata and Michiyo Honda *(D)
}

Department of Applied Chemistry, Graduate School of Science and Technology, Meiji University, 1-1-1

Higashimita, Kawasaki 214-8571, Japan; victor.franken.stein.lab@gmail.com

* Correspondence: michiyoh@meiji.ac.jp; Tel.: +81-44-934-7210

Citation: Inomata, K.; Honda, M. Moderate Hypothermia Has the

Potential to Reveal the

Dominant/Submissive Relationship in a Co-Culture System Consisting of Osteoblasts and Endothelial Cells. Micro 2021, 1, 181-193. https:// doi.org/10.3390/micro1020014

Academic Editor: Valeria Chiono

Received: 13 July 2021

Accepted: 21 September 2021

Published: 27 September 2021

Publisher's Note: MDPI stays neutral with regard to jurisdictional claims in published maps and institutional affiliations.

Copyright: (c) 2021 by the authors. Licensee MDPI, Basel, Switzerland. This article is an open access article distributed under the terms and conditions of the Creative Commons Attribution (CC BY) license (https:// creativecommons.org/licenses/by/ $4.0 /)$.

\begin{abstract}
Microvessels in bone are indispensable for maintaining bone homeostasis based on a dynamic remodeling system. In cell-based tissue engineering, vascularization into the regenerative bone is a key strategy to avoid hypoxia and necrosis around re-implanted tissues. Previous studies have shown that direct contact between osteoblasts and endothelial cells stimulates differentiation of both cell types. However, no studies have revealed the dominant/submissive relationship. In the present study, we examined the effect of hypothermia on monoculture and co-culture to assess which cells tightly coordinated osteogenesis and angiogenesis in the co-culture system. As for osteoblasts, exposure to hypothermia suppressed cellular proliferation, migration, and differentiation. Evaluation of the behavior of endothelial cells showed that hypothermia should not affect basic functions such as proliferation and migration. Under co-culture conditions, both osteogenic differentiation and the formation of vessel-like angiogenic structures were suppressed by hypothermia, but the spatial organization of alkaline phosphatase-positive cell clusters, which tend to localize around microvascular lumens, was not altered. These data suggest that hypothermia attenuates heterotypic intercellular crosstalk which robustly depends on osteoblasts to inhibit both osteogenesis and angiogenesis in the co-culture system. Taken together, this approach will provide new insights into the relationship between osteoblasts and endothelial cells in tissue engineering.
\end{abstract}

Keywords: angiogenesis; co-culture; endothelial cell; hypothermia; osteoblast; osteogenesis

\section{Introduction}

Architecture of hierarchical structures and orchestrated systems is a major challenge in tissue engineering. Bone has a regenerative capacity yet fails to repair critical-sized defects [1]. There are different approaches to treat damaged and/or defective tissues. Autologous bone grafting is the gold standard for bone defect treatment [2]. An iliac crest, which is most frequently used for autografting, can introduce angiogenesis to express the osteoinductive, osteoconductive, and osteogenic potential around the re-implanted area [3-5]. However, this approach has a lot of limitations, such as the amount of material available and post-operative pain.

Bone has a dynamic remodeling system that is robustly coupled with vascularization. Microvasculature in bone is essential to supply nutrients and oxygen, remove metabolic wastes, and transport growth factors and inorganic ions. A lack of vascular systems can cause hypoxia and cell necrosis, resulting in clinical problems [6-8]. The complex tissue is supported by the periosteum. The periosteum is a highly vascularized connective tissue sheath covering the surface of bone and is composed of two distinct layers, termed "fibrous layer" and "cambium layer". The periosteum has multiple roles in maintaining bone homeostasis: storage of growth factors and inorganic ions; a source of mesenchymal lineage cells and vascular endothelial cells; and an origin of osteogenesis and angiogenesis $[9,10]$. The osteoimmune system originates from blood vessels in the periosteum and periosteal 
circulation [11]. Thus, constructing regenerative bone like periosteum has attracted much attention in the field of bone tissue engineering.

Co-culture of osteoblasts and endothelial cells has been used not only to construct periosteum-like tissue but also to investigate the spatiotemporal relationship between osteogenesis and angiogenesis. Previous studies have demonstrated that co-culture of osteoblasts and endothelial cells induces the differentiation of both cell types, such as the enhancement of osteogenic differentiation and the formation of vessel-like angiogenic structures [12-14]. It has been considered that these effects may be mediated by heterotypic intercellular crosstalk via humoral factors, cell junctions, and extracellular matrices [15-17]. In particular, direct contact between osteoblasts and endothelial cells should strongly reflect both paracrine and juxtacrine crosstalk mechanisms [18]. Moreover, physical stimulations such as hypoxia and shear stress contribute to promoting osteogenesis and angiogenesis by regulating the communications $[19,20]$. Since they cannot selectively target either cell type, however, the dominant/submissive relationship remains undefined.

Due to this background, we focused on a thermal approach to reveal which cells dominated the regulation of a co-culture system of osteoblasts and endothelial cells. Some studies have shown that mild hyperthermia $\left(39^{\circ} \mathrm{C}\right)$ promotes osteoblastic proliferation and differentiation, whereas moderate hypothermia $\left(33^{\circ} \mathrm{C}\right)$ represses osteoblastic proliferation, differentiation, and endothelial cell apoptosis in monoculture conditions [21-24]. In another study, mild heat shock enhanced both osteogenesis and angiogenesis in a co-culture system of osteoblasts and endothelial cells [25]. The exposure of a co-culture system to the effects of hyperthermia could hardly reveal the dominant/submissive relationship between both cell types, owing to the low specificity. No studies have yet treated cells with moderate hypothermia, to our knowledge. Therefore, the cell-specific response to moderate hypothermia will be key in revealing the dominant/submissive relationship between osteoblasts and endothelial cells. In the present study, to examine which cells positively affect the co-culture system, we investigated the effect of moderate hypothermia $\left(33^{\circ} \mathrm{C}\right)$ on different culture conditions: monoculture of either osteoblasts or endothelial cells and co-culture of osteoblasts and endothelial cells. This approach will provide new insights into the relationship between osteogenesis and angiogenesis during bone regeneration.

\section{Materials and Methods}

\subsection{Cell Culture}

Commercially available human osteoblast-like MG-63 cells (ATCC ${ }^{\circledR}$ CRL-1427'M and human umbilical vein endothelial cells (HUVECs; PromoCell, Heidelberg, Germany) were used as models of osteoblasts and endothelial cells in the present study. MG-63 cells were cultured in Eagle's minimum essential medium (Sigma-Aldrich, St. Louis, MO, USA) supplemented with 10\% heat-inactivated fetal bovine serum (FUJIFILM Wako Pure Chemical, Osaka, Japan), 1\% non-essential amino acids (Sigma-Aldrich, St. Louis, MO, USA), 100 units $\mathrm{mL}^{-1}$ penicillin (FUJIFILM Wako Pure Chemical, Osaka, Japan), and $100 \mu \mathrm{g} \cdot \mathrm{mL}^{-1}$ streptomycin (FUJIFILM Wako Pure Chemical, Osaka, Japan). HUVECs were cultured in Endothelial Cell Growth Medium 2 kit (EGM2; Takara Bio Inc., Shiga, Japan). Both MG-63 cells and HUVECs were maintained at $37^{\circ} \mathrm{C}$ in a humidified atmosphere containing 5\% $\mathrm{CO}_{2}$. All experiments were conducted using MG-63 cells at passage 3-6 and HUVECs at passage 1-3.

\subsection{Cell Proliferation}

Cells were seeded at $1.0 \times 10^{4}$ cells $\cdot \mathrm{cm}^{-2}$ in 6- or 24-well plates with growth medium and cultured at $37^{\circ} \mathrm{C}$ and $33^{\circ} \mathrm{C}$ for $1,3,5$, and 7 days. The culture medium was refreshed every 2 days. The number of proliferating cells was assessed by direct cell counting or crystal violet staining after the appropriate incubation period. Direct cell counting was to count the cells collected by trypsinization with a hemocytometer. Crystal violet staining was performed according to a modified procedure [26]. Briefly, after rinsing with phosphatebuffered saline (PBS; pH 7.4), cells were fixed with 4\% paraformaldehyde/PBS for $15 \mathrm{~min}$. 
The fixed cells were stained with $0.1 \%$ crystal violet solution at room temperature for $30 \mathrm{~min}$. The bound stain was extracted at room temperature for $15 \mathrm{~min}$ with $1 \%$ sodium dodecyl sulfate solution. The absorbance was measured at $570 \mathrm{~nm}$ using a microplate reader (Multiskan FC, Thermo Fisher SCIENTIFIC, Waltham, MA, USA). The cell number was determined according to a standard curve established using known numbers of cells.

\subsection{Cell Migration}

Cells were seeded at $5.0 \times 10^{4}$ cells $\cdot \mathrm{cm}^{-2}$ in 24 -well plates with growth medium and precultured at $37{ }^{\circ} \mathrm{C}$ for $24 \mathrm{~h}$. The cells were scraped off with a pipet tip and the medium was exchanged. Phase contrast pictures were taken at 0 and $24 \mathrm{~h}$ with a fluorescence phase-contrast microscope (BZ X-710, Keyence, Osaka, Japan). The intracellular distance was measured using ImageJ software (version $1.52 \mathrm{~h}$, National Institutes of Health (NIH), Bethesda, MD, USA). Cell migration was determined by the distance moved into the acellular area over time.

\subsection{Osteoblastic Differentiation}

MG-63 cells were seeded at $2.5 \times 10^{4} \mathrm{cells} \cdot \mathrm{cm}^{-2}$ in 24 -well plates with growth medium and precultured at $37^{\circ} \mathrm{C}$ and $33^{\circ} \mathrm{C}$ for 3 days. After that, the medium was exchanged for differentiation-induction medium: growth medium supplemented with $10 \mathrm{mM}$ $\beta$-glycerophosphate (FUJIFILM Wako Pure Chemical, Osaka, Japan), $50 \mu \mathrm{g} \cdot \mathrm{mL}^{-1}$ ascorbic acid (Sigma-Aldrich, St. Louis, MO, USA), and $100 \mathrm{nM}$ dexamethasone (FUJIFILM Wako Pure Chemical, Osaka, Japan). The culture medium was refreshed every 2 days and the culture was maintained at $37^{\circ} \mathrm{C}$ and $33^{\circ} \mathrm{C}$ for a maximum of 21 days. Briefly, cells were collected by trypsinization and stored at $-80^{\circ} \mathrm{C}$ every 7 days. For each time point, intracellular alkaline phosphatase (ALP) activity was determined, referring to the manufacturer's instructions for LabAssay ${ }^{\mathrm{TM}}$ ALP (FUJIFILM Wako Pure Chemical, Osaka, Japan).

\subsection{Endothelial Cell Tube Formation}

Each well of a 24-well plate was coated with $250 \mu \mathrm{L}$ of Matrigel ${ }^{\circledR}$ Basement Membrane Matrix (Corning, Bedford, MA, USA) without trapping air bubbles and settled at $37{ }^{\circ} \mathrm{C}$ for at least $30 \mathrm{~min}$ as allowance for gelation of Matrige ${ }^{\circledR}$ Matrix. HUVECs were seeded at $5.0 \times 10^{4}$ cells $\cdot \mathrm{cm}^{-2}$ in each well of a 24 -well plate coated with Matrigel ${ }^{\circledR}$ Basement Membrane Matrix and incubated at $37^{\circ} \mathrm{C}$ and $33^{\circ} \mathrm{C}$ for $6 \mathrm{~h}$. At the culture step, the cells were observed under a phase-contrast microscope (CKX53-11BFK and DP21-SAL, Olympus, Tokyo, Japan). The tube formation images were quantified using Angiogenesis Analyzer for ImageJ software [27].

\subsection{Co-Culture of Osteoblasts and Endothelial Cells}

MG-63 cells and HUVECs were, respectively, seeded at an initial density of $2.0 \times 10^{4}$ cells $\cdot \mathrm{cm}^{-2}$ and $8.0 \times 10^{4} \mathrm{cells} \cdot \mathrm{cm}^{-2}$ in each well of a 24 -well plate in EGM2 and precultured at $37^{\circ} \mathrm{C}$ for $24 \mathrm{~h}$ as previously described [28]. The culture medium was refreshed every 2 days and the culture was maintained at $37^{\circ} \mathrm{C}$ and $33^{\circ} \mathrm{C}$ for a maximum of 21 days.

\subsection{Quantitative Measurement of Alkaline Phosphatase Activity}

Alkaline phosphatase (ALP) activity was determined by a colorimetric analysis using p-nitrophenyl phosphate as substrate, referring to the manufacturer's instructions for LabAssay $^{\mathrm{TM}}$ ALP (FUJIFILM Wako Pure Chemical, Osaka, Japan). Briefly, cells were collected by trypsinization and stored at $-80{ }^{\circ} \mathrm{C}$ every 7 days. For each time point, the samples were solubilized with CelLytic ${ }^{\mathrm{TM}} \mathrm{M}$ (Sigma-Aldrich, St. Louis, MO, USA) and homogenized by sonication. The cell lysates were centrifuged, and the supernatants were then assayed for ALP. The absorbance was measured at $405 \mathrm{~nm}$ using a microplate reader (Multiskan FC, Thermo Fisher SCIENTIFIC, Waltham, MA, USA). One unit was defined as the activity that produced one nanomole of $p$-nitrophenol after $15 \mathrm{~min}$. Enzymatic activity was normalized 
to total protein concentration using bovine serum albumin (BSA; FUJIFILM Wako Pure Chemical, Osaka, Japan). Total protein concentrations of the supernatants were determined by the standard method of Bradford (FUJIFILM Wako Pure Chemical, Osaka, Japan).

\subsection{Immunofluorescence Analysis of CD31 Expression}

Cells were washed twice with PBS and fixed with $4 \%$ paraformaldehyde/PBS at room temperature for $15 \mathrm{~min}$. The cells were then permeabilized with $0.1 \%$ Triton X-100/PBS at room temperature for $15 \mathrm{~min}$. After rinsing with PBS twice, the cells were blocked with 3\% BSA/PBS at room temperature for $1 \mathrm{~h}$ and then incubated with monoclonal mouse antihuman CD31 antibody (Dako, Glostrup, Denmark) diluted in PBS at $4{ }^{\circ} \mathrm{C}$ overnight. The

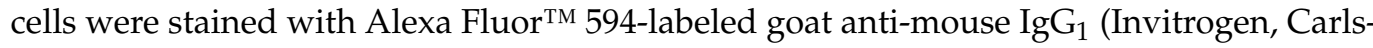
bad, CA, USA) for CD31 and 4',6-diamino-2-phenylindole (DAPI; Dojindo, Kumamoto, Japan) for nuclei diluted in PBS. The cells were again washed with PBS and then examined with a fluorescence phase-contrast microscope (BZ X-710, Keyence, Osaka, Japan).

\subsection{Histochemical Staining for ALP Activity and Immunocytochemical Staining for CD31 Expression}

Histochemical staining for ALP activity was performed using a commercially available kit (FUJIFILM Wako Pure Chemical, Osaka, Japan), referring to the manufacturer's procedure. Briefly, cells were washed with PBS and fixed with $4 \%$ paraformaldehyde/PBS for $15 \mathrm{~min}$. The cells were then permeabilized with acetone/methanol $\left(-20^{\circ} \mathrm{C}\right)$ at room temperature for $2 \mathrm{~min}$. After rinsing with PBS twice, the cells were stained with ALP substrate solution (premixed) at $37^{\circ} \mathrm{C}$ for $45 \mathrm{~min}$. Immunocytochemical staining for CD31 expression was performed using Vectastain ${ }^{\circledR}$ Elite $^{\circledR}$ ABC Universal PLUS kit (Vector Laboratories, Burlingame, CA, USA) following the manufacturer's protocol. The cells were washed with PBS twice and blocked with BLOXALL ${ }^{\circledR}$ blocking solution at room temperature for $10 \mathrm{~min}$. After washing with PBS twice, the cells were blocked with 3\% BSA/PBS at room temperature for $1 \mathrm{~h}$ and then incubated with monoclonal mouse anti-human CD31 antibody (Dako, Glostrup Denmark) diluted in PBS at $4{ }^{\circ} \mathrm{C}$ overnight. The cells were incubated with biotinylated horse anti-mouse/rabbit IgG secondary antibody diluted in PBS at room temperature for $30 \mathrm{~min}$. The cells were rinsed with PBS and then treated with Vectastain Elite $\mathrm{ABC}$ reagent at room temperature for $30 \mathrm{~min}$. After washing with PBS, the cells were stained with ImmPACT DAB EqV solution at room temperature for $15 \mathrm{~min}$. The cells were again washed with PBS and then examined with a fluorescence phase-contrast microscope (BZ X-710, Keyence, Osaka, Japan).

\subsection{Statistical Analysis}

The data were statistically analyzed for determination of the mean and the standard deviation (SD) of the mean. The Student's $t$-test was carried out with a significance level of $p<0.05$.

\section{Results}

\subsection{Effect of Hypothermia on the Osteoblast and the Endothelial Cell Monocultures}

Osteoblasts are involved in a bone remodeling system directly linked to bone mass. Some studies have reported that osteoblastic functions are suppressed under unsuitable conditions, thereby inhibiting calcification [29-31]. On the other hand, microvessels are present in most tissues and are indispensable for homeostasis by the circulatory system. Angiogenesis, which involves the formation of new blood vessels in tissues, relies upon proliferation and migration of vascular endothelial cells [32,33].

In the present study, MG-63 cells and endothelial cells were monocultured at low temperature $\left(33^{\circ} \mathrm{C}\right)$ to investigate the effects of hypothermia on osteoblasts. First, cells were seeded on tissue culture plates to examine the effect of hypothermia on cellular proliferation. At days 1, 3, 5, and 7 after seeding, cells were counted according to the described methods. Measurements for the osteoblast monoculture showed that it took more time to reach confluence under hypothermia (Figure 1A). The observations with an optical microscope also confirmed that the cells under normal conditions $\left(37^{\circ} \mathrm{C}\right)$ 
reached confluence at 5 days after plating, whereas the cells under hypothermic conditions $\left(33^{\circ} \mathrm{C}\right)$ reached confluence at 7 days after plating (data not shown). In addition, exposure to moderate cold shock also prolonged the doubling time during the exponential growth phase (Figure 1B). No evident changes were observed between normal and hypothermic endothelial cell monoculture conditions (Figure 1A,B).

A

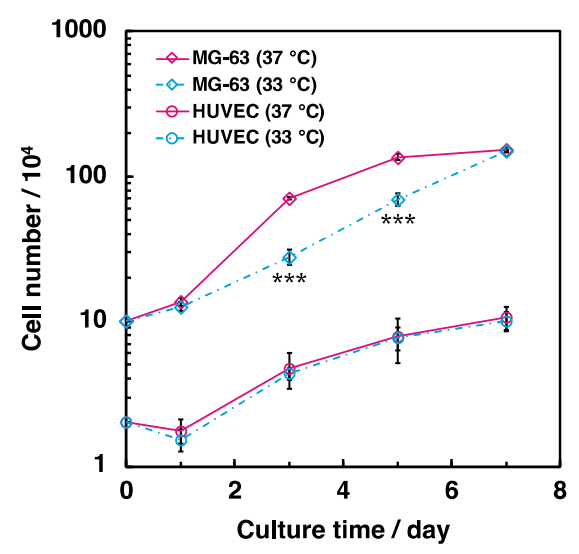

B

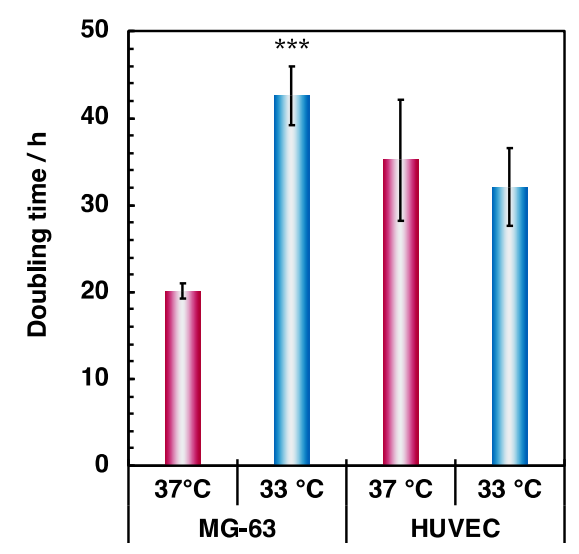

Figure 1. Comparison of cellular proliferation in MG-63 cells and HUVECs. To examine the effect of hypothermia on proliferation of osteoblasts and endothelial cells, cells were cultured in 6- or 24-well plates at $37^{\circ} \mathrm{C}$ and $33^{\circ} \mathrm{C}$ for 7 days. (A) The number of proliferating cells were counted at days 1,3 , 5 , and 7 after seeding. (B) Doubling time was calculated by the ratio of the cell number during the $\log$ phase. Data were collected from six replicate samples and are shown as mean \pm SD. ${ }^{* * *} p<0.001$ compared with $37^{\circ} \mathrm{C}$.

Next, a scratch-wound assay was performed to investigate the influence of hypothermia on cellular migration. In bone tissue, osteoblasts and endothelial cells migrate into resorption lacunae to grow and differentiate for bone formation $[34,35]$. Therefore, cellular migration can be used as an index for estimating osteogenesis and angiogenesis in bone tissue. Incubation at lower temperature decreased cellular migration in MG-63 cells compared to normal culture conditions (Figure 2A,C). No significant differences between the different conditions were observed in the endothelial cell monoculture (Figure 2B,C).

Furthermore, we evaluated the effect of hypothermia on osteoblastic differentiation. The ALP activity of cells cultured in hypothermic conditions significantly decreased for all culture periods (Figure 3). These data suggest that hypothermia negatively affects osteoblastic functions, reducing the osteogenic capacity, in agreement with previous studies [21,22]. However, culturing HUVECs on the Matrigel ${ }^{\circledR}$ Basement Membrane Matrix in hypothermic conditions tended to enhance tube formation (Figure 4). These results suggest that hypothermia should not affect the functions of vascular endothelial cells, such as cellular proliferation and migration, except for tube formation in the presence of rich extracellular matrices, but may attenuate osteoblastic proliferation, migration, and differentiation. 
A

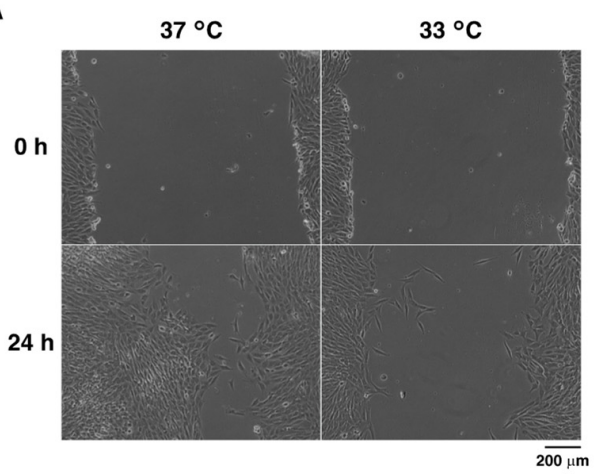

C

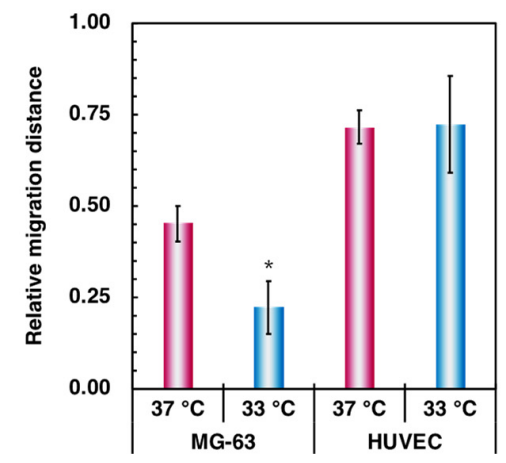

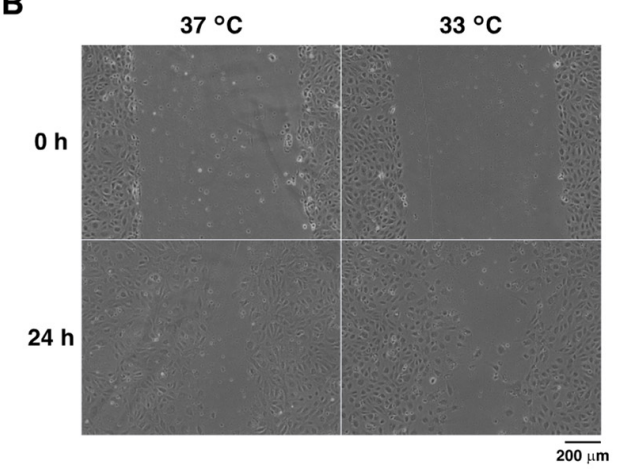

Figure 2. Comparison of cellular migration in (A) MG-63 cells and (B) HUVECs. To examine the effect of hypothermia on migration of osteoblasts, a scratch-wound assay was performed as described in Materials and Methods. (A,B) At the culture step, the cells were viewed with a phase-contrast microscope at $10 \times$ magnification (scale bar: $200 \mu \mathrm{m}$ ). (C) The relative migration distance was calculated by the ratio between the initial intracellular distance and the final intracellular distance. Data were collected from three replicate samples and are shown as mean $\pm \mathrm{SD}$. ${ }^{*} p<0.05$ compared with $37^{\circ} \mathrm{C}$.

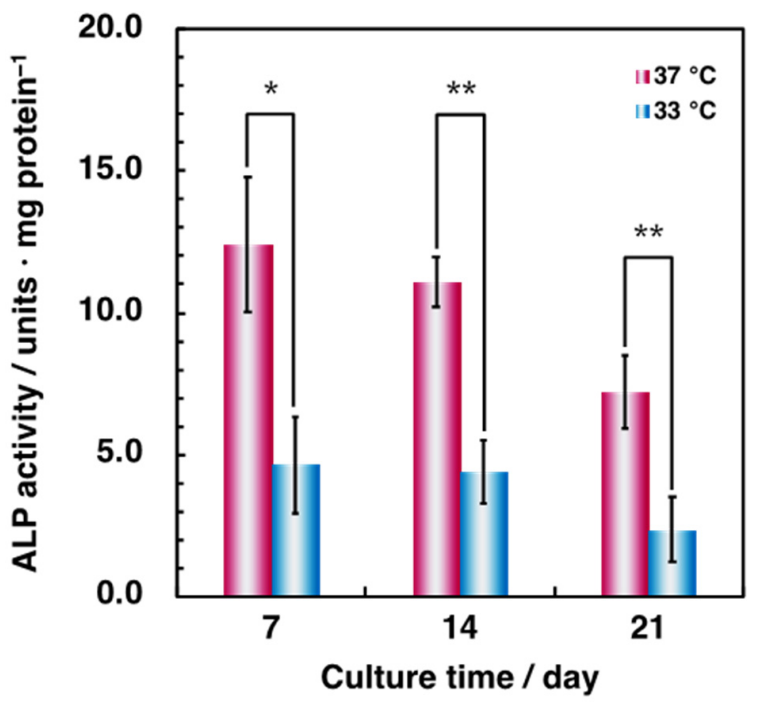

Figure 3. Comparison of osteoblastic differentiation in MG-63 cells. To examine the effect of osteoblastic differentiation by hypothermia, cells were precultured at $37^{\circ} \mathrm{C}$ and differentiation-induced at $37^{\circ} \mathrm{C}$ and $33^{\circ} \mathrm{C}$ for 21 days. Intracellular ALP activity was measured at days 7,14 , and 21 after differentiation-inducing. ALP activity was assessed using the $p$-nitrophenyl phosphate substrate assay described in Materials and Methods. Data were collected from three replicate samples and are shown as mean $\pm \mathrm{SD} .{ }^{*} p<0.05 ;{ }^{* *} p<0.01$ compared with $37^{\circ} \mathrm{C}$. 
A $37^{\circ} \mathrm{C}$ $33^{\circ} \mathrm{C}$

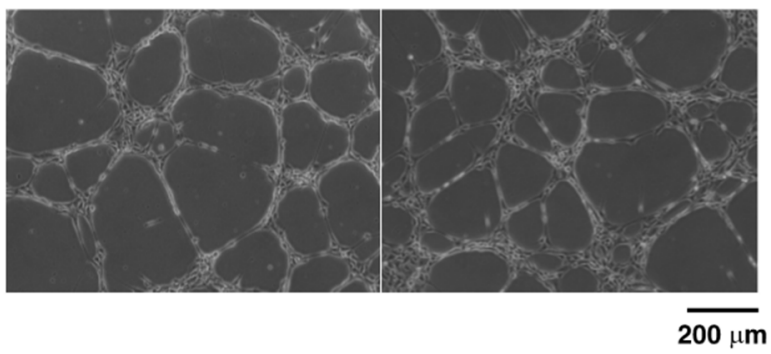

B
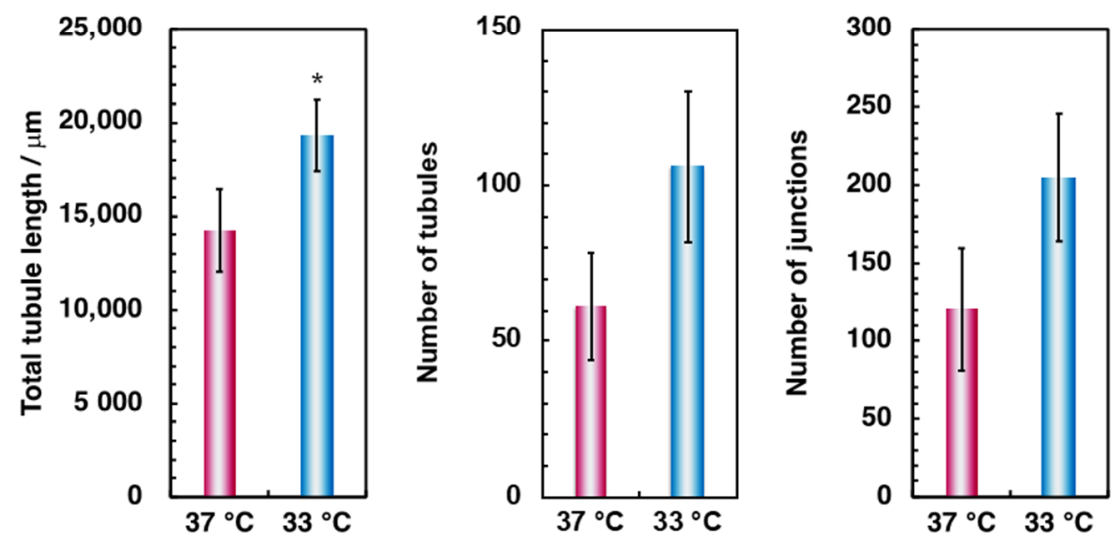

Figure 4. Comparison of endothelial cell tube formation in HUVECs. To examine the effect of hypothermia on endothelial cell tube formation, cells were cultured on the Matrigel ${ }^{\circledR}$ Basement Membrane Matrix at $37^{\circ} \mathrm{C}$ and $33{ }^{\circ} \mathrm{C}$ for $6 \mathrm{~h}$. The cells were (A) viewed with a phase-contrast microscope at $10 \times$ magnification (scale bar: $200 \mu \mathrm{m}$ ) and (B) assessed using Angiogenesis Analyzer for ImageJ software. Data were collected from three replicate samples and are shown as the mean \pm SD. ${ }^{*} p<0.05$ compared with $37^{\circ} \mathrm{C}$.

\subsection{Effects of Hypothermia on the Co-Culture of Osteoblasts and Endothelial Cells}

Co-culture of osteoblasts and endothelial cells can reinforce both osteogenesis and angiogenesis and thus provides a crucial tool for the construction of a regenerative periosteum with vascular networks [12-14]. However, it remains unclear which cells dominate the regulation of osteogenesis and angiogenesis in the co-culture system. In the present study, we exposed the co-culture system to hypothermic conditions to reveal the dominant/submissive relationship between osteoblasts and endothelial cells.

First, to investigate the effect of hypothermia on osteoblastic differentiation in the coculture system, bone-specific ALP activity was quantitated using a $p$-nitrophenyl phosphate substrate assay. The ALP activity under hypothermic culture conditions was about two times lower compared to that under normal culture conditions during all culture periods (Figure 5). These results agreed with observations from the monoculture of osteoblasts (Figure 3). These data indicate that hypothermia suppresses osteoblastic differentiation in both monoculture and co-culture conditions. 


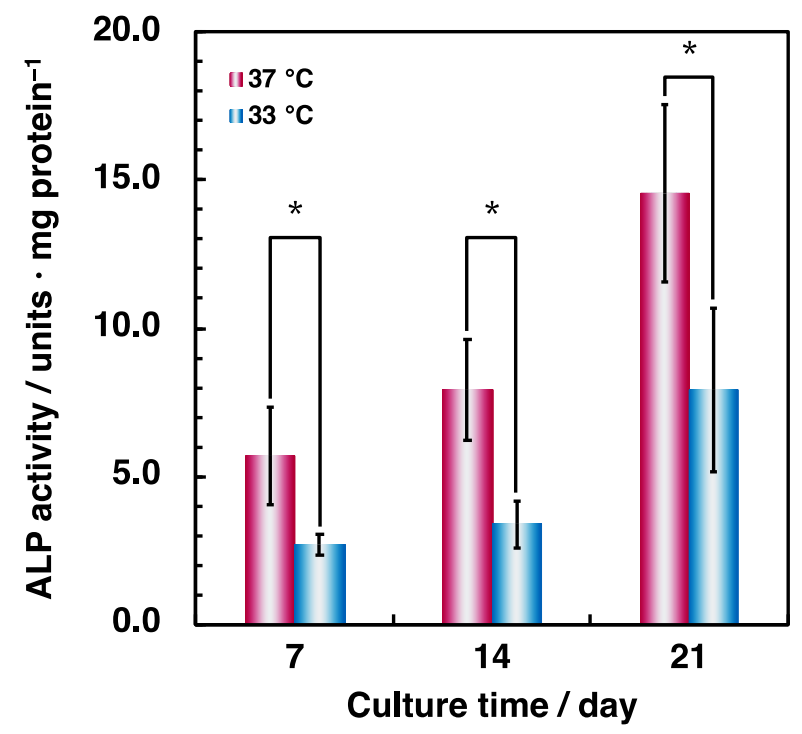

Figure 5. Comparison of ALP activity in co-culture cells. MG-63 cells and HUVECs were, respectively, seeded at an initial density of $2.0 \times 10^{4} \mathrm{cells} \cdot \mathrm{cm}^{-2}$ and $8.0 \times 10^{4}$ cells $\cdot \mathrm{cm}^{-2}$ in 24-well plates and precultured at $37^{\circ} \mathrm{C}$ for $24 \mathrm{~h}$. Cells were cultured at $37^{\circ} \mathrm{C}$ and $33^{\circ} \mathrm{C}$ for 7,14 , and 21 days. ALP activity was assessed using the $p$-nitrophenyl phosphate substrate assay described in Materials and Methods. Data were collected from three replicate samples and are shown as mean \pm SD. ${ }^{*} p<0.05$ compared with $37^{\circ} \mathrm{C}$.

Next, to examine tube formation by endothelial cells under hypothermia, CD31 and nuclei were observed by immunofluorescence microscopy. Microcapillary-like structures were formed under normal and hypothermic culture conditions (arrowheads in Figure 6). There was a tendency towards decreased formation of microvascular lumens under hypothermia. In contrast, exposing cells on the Matrige ${ }^{\circledR}$ Basement Membrane Matrix to moderate cold shock significantly increased the formation of vessel-like structures (Supplementary Materials, Figure S1). These results show that hypothermia attenuates angiogenesis on poor extracellular matrices, whereas vascularization is stimulated on rich extracellular matrices in the co-culture system.

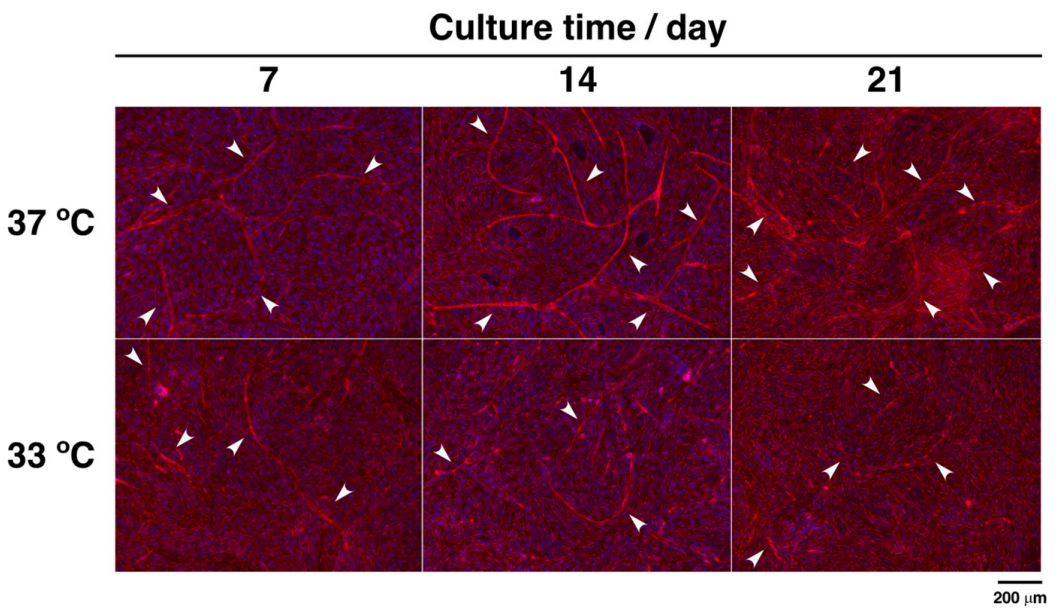

Figure 6. Immunofluorescence analysis of CD31 expression in co-culture cells. MG-63 cells and HUVECs were, respectively, seeded at an initial density of $2.0 \times 10^{4}$ cells $\cdot \mathrm{cm}^{-2}$ and $8.0 \times 10^{4} \mathrm{cells} \cdot \mathrm{cm}^{-2}$ in 24-well plates and precultured at $37^{\circ} \mathrm{C}$ for $24 \mathrm{~h}$. Cells were cultured at $37^{\circ} \mathrm{C}$ and $33^{\circ} \mathrm{C}$ for 7 , 14 , and 21 days. At the culture step, the cells were fixed and stained with anti-CD31 for CD31 (red) and DAPI for nuclei (blue). They were viewed with a fluorescence phase-contrast microscope at $10 \times$ magnification (scale bar: $200 \mu \mathrm{m}$ ). Arrowheads show microcapillary-like structures. 
Furthermore, to confirm heterotypic intercellular crosstalk between osteoblasts and endothelial cells, bone-specific ALP and vasculature-specific CD31 were visualized by a dual histochemical staining and immunocytochemical staining. As with the immunofluorescence analysis of CD31 expression (Figure 7), CD31-positive cells assembled in rows to form the microcapillary-like structures (arrowheads in Figure 7). ALP-positive cells also tended to accumulate around the formed microvascular lumens. In addition, we observed that connexin 43 , also known as gap junction alpha 1 protein, localized between CD31-positive cells and CD31-negative cells during short culture periods (Supplementary Materials, Figure S2). These data suggest that both osteoblasts and endothelial cells communicate by direct contact regardless of the culture conditions.

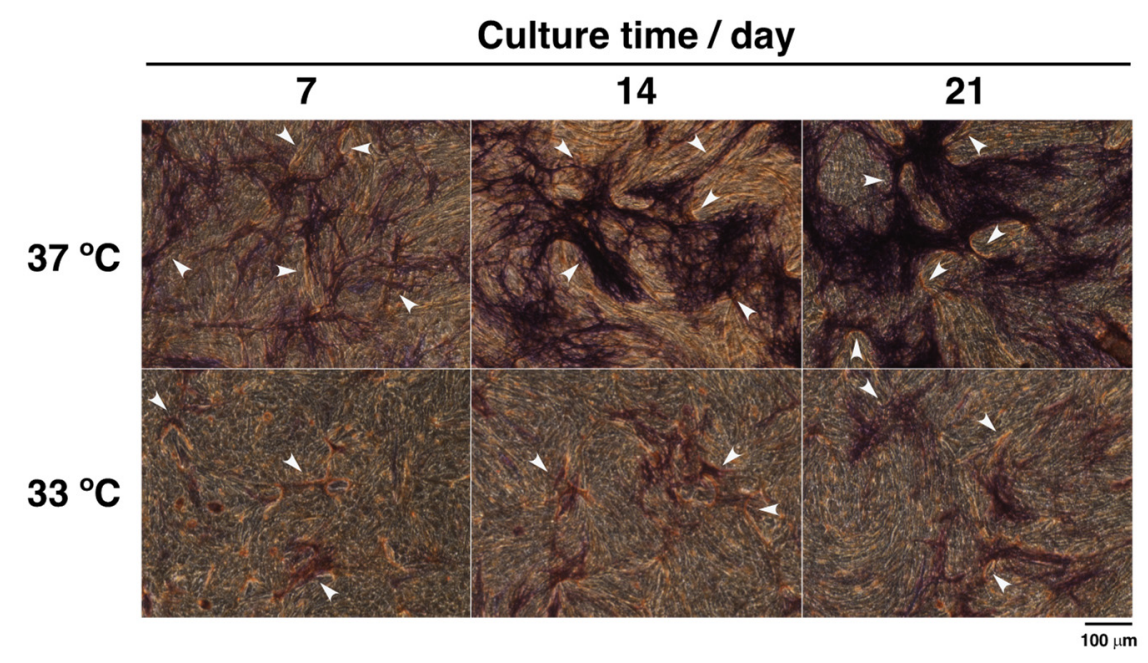

Figure 7. Histochemical staining for ALP activity and immunocytochemical staining for CD31 expression in co-culture cells. MG-63 cells and HUVECs were, respectively, seeded at an initial density of $2.0 \times 10^{4}$ cells $\cdot \mathrm{cm}^{-2}$ and $8.0 \times 10^{4}$ cells $\cdot \mathrm{cm}^{-2}$ in 24 -well plates and precultured at $37^{\circ} \mathrm{C}$ for $24 \mathrm{~h}$. Cells were cultured at $37^{\circ} \mathrm{C}$ and $33^{\circ} \mathrm{C}$ for 7,14 , and 21 days. At the culture step, the cells were fixed and stained for ALP activity (purple) and CD31 (brown). They were viewed with a fluorescence phase-contrast microscope at $20 \times$ magnification (scale bar: $100 \mu \mathrm{m}$ ). Arrowheads show microcapillary-like structures.

\section{Discussion}

The absence of microvessels in engineered tissues leads to low cell viability and cell death, due to a shortage of blood circulation. To overcome these problems, a variety of strategies have been proposed and developed to effectively induce vascularization around the tissue [36,37]. In bone tissue engineering, the periosteum has attracted much attention. A co-culture system of osteoblasts and endothelial cells was used to mimic the periosteumlike tissue. However, the dominant/submissive relationship remains undefined in the co-culture system, due to the lack of inhibitors that selectively target either cell. Therefore, we focused on thermal stimulation. Previous studies showed that moderate hypothermia suppressed osteoblastic proliferation and differentiation, while viability of endothelial cells was sustained [21-24]. Based on the above, we hypothesized that if hypothermia inhibited either of the two cell types, it would have been possible to examine which cells dominantly controlled the co-culture system.

In the present study, we investigated the effect of hypothermia on monocultures of osteoblasts and endothelial cells as well as a co-culture with both cell types. First, hypothermia suppressed cellular functions, such as proliferation, migration, and differentiation, in the monoculture of osteoblasts, consistent with results from previous studies [21,22]. Some studies have shown that exposing osteoblasts to hypothermia induces the expression of RNA-binding motif protein 3 (RBM3) [38,39]. This protein belongs to a small group of chaperone-like proteins whose synthesis increases during hypothermia, in contrast to 
the general decrease in protein synthesis. RBM3 has been known to prevent cell apoptosis by regulating the cell cycle and to delay other functions, such as proliferation and differentiation [40]. Likewise, heat shock proteins (HSPs) are a family of intracellular chaperones activated under stressful conditions, such as hyperthermia and hypothermia, and HSP70 prevents protein misfolding during synthesis to contribute to cell survival [41,42]. Therefore, it is possible that hypothermia-induced RBM3 may attenuate the osteoblastic potential, whereas HSP70 may inhibit cell death to maintain viability. However, detailed mechanisms are unknown.

Next, we found that hypothermia did not affect endothelial cell proliferation and migration on tissue culture plates but stimulated tube formation on the Matrige ${ }^{\circledR}$ Basement Membrane Matrix in the monoculture of endothelial cells. A previous study demonstrated that endothelial cells under hypothermia averted ischemia/reperfusion-induced apoptosis via the c-Jun N-terminal kinase (JNK) signaling pathway [23]. The JNK signaling pathway may be important for endothelial cells in producing matrix metalloproteases (MMPs) [43]. Hence, it is considered that vascular endothelial cells can form angiogenic microcapillary-like structures with the use of MMPs on environments with extracellular matrices but sustain only proliferation and migration in other environments under hypothermia. However, these pathways have not been identified.

Finally, we co-cultured osteoblasts with endothelial cells to examine the effect of hypothermia on osteogenesis and angiogenesis in co-culture. Hypothermia negatively affected osteoblastic differentiation and endothelial cell tube formation on tissue culture plates. In contrast, tube formation was promoted on the Matrige $\mathrm{l}^{\circledR}$ Basement Membrane Matrix. Additionally, combined histochemical and immunocytochemical staining indicated that osteoblasts and endothelial cells can crosstalk by direct contact under both normal and hypothermic culture conditions. Previous studies have shown that gap junctions contribute to osteogenesis and angiogenesis in the co-culture system over short to long periods $[16,44]$ and transmit signals from activated cells to other cells [12,15]. Moreover, osteoblasts may more readily produce an extracellular matrix than endothelial cells in the co-culture system $[17,45,46]$. Humoral factors are also important elements [47], whereas there is possibly a negative correlation between soluble factors and cell junctions [48,49]. Even so, osteoblasts accept growth factors-including bone morphogenetic protein and plate-derived growth factor-secreted by endothelial cells to work as both bone-forming cells and pericytes. In addition, endothelial cells use the paracrine pathway via vascular endothelial growth factor, interleukin, and so on produced by osteoblasts to form microvessels. As a result, osteoblasts and endothelial cells may possibly change their morphology to suit the in vivo bone environment, but the effects under hypothermia were insufficiently verified by the present study. Thus, these data suggest that hypothermia has no effect on endothelial cells but only inhibits osteoblastic activity, attenuating cell signaling via intercellular junctions and extracellular matrices, and thereby ostensibly reducing the overall functions of the co-culture system. From the results, it could be considered that osteoblasts dominantly regulate the co-culture system; however, additional studies are warranted to elucidate the dominant/submissive relationship between osteoblasts and endothelial cells.

Taken together, hypothermia did not affect endothelial cell proliferation and migration and suppressed osteoblastic proliferation, migration, and differentiation, inhibiting osteogenesis and angiogenesis in co-cultures. Therefore, this approach highlighted the dominant role of osteoblasts in controlling the co-culture system. As described above, the strategy of vascularization into regenerative tissue is key for the survival of cells and tissues. In cell-based tissue engineering, it is indispensable to construct and maintain robust intracellular contacts $[50,51]$. Based on this perspective, the enhancement of osteogenesis is as crucial as the induction of angiogenesis in the osteoblast and endothelial cell co-culture system in order to construct periosteum-like tissue with vascular networks. However, one limitation is that it was not possible to completely separate and disperse the co-cultured cells for a long period, and, thus, probes such as for gene expression were not available 
for quantification. If it was possible to resolve these challenges, new insights into the relationship would be achieved.

In summary, our results demonstrated that hypothermia did not affect the fundamental functions of endothelial cells and suppressed osteoblastic proliferation, migration, and differentiation in monoculture conditions. Additionally, hypothermia reduced osteoblastic differentiation and endothelial cell tube formation under the co-culture conditions. These data suggest that hypothermia should attenuate osteoblast-dependent cell communication via gap junctions and extracellular matrices, preventing both osteogenesis and angiogenesis in the co-culture system. However, the mechanisms lack detail. Further studies will provide new insights into the relationship between osteogenesis and angiogenesis during bone regeneration. For the present, this approach suggests that osteoblasts may be dominant and endothelial cells may be submissive in the co-culture system.

\section{Conclusions}

Highly vascularized regenerative bone, such as the periosteum, is key to reconstructing large skeletal defects. Co-culture of osteoblasts and endothelial cells induces the differentiation of both cell types via heterotypic intercellular crosstalk. However, the dominant/submissive relationship remains undefined. In the present study, we investigated the effects of hypothermia on monocultures and co-cultures of osteoblasts and endothelial cells. Our results demonstrated that hypothermia did not affect the fundamental functions of endothelial cells and suppressed osteoblastic proliferation, migration, and differentiation in monoculture conditions. Additionally, hypothermia reduced osteoblastic differentiation and endothelial cell tube formation under the co-culture conditions. These data suggest that hypothermia attenuates osteoblast-dependent cell communication via gap junctions and extracellular matrices, preventing both osteogenesis and angiogenesis in the co-culture system. Further studies will provide new insights into the relationship between osteogenesis and angiogenesis during bone regeneration. Taken together, this approach suggests that osteoblasts may be dominant and endothelial cells may be submissive in the co-culture system.

Supplementary Materials: The following are available online at https:/ /www.mdpi.com/article/10 .3390/micro1020014/s1, Figure S1: Endothelial cell tube formation; Figure S2: Immunofluorescent staining for connexin 43 expression.

Author Contributions: Conceptualization, K.I. and M.H.; Investigation, K.I; Methodology, K.I. and M.H.; Writing, K.I. and M.H.; Writing—review and editing, M.H.; Visualization, K.I.; Supervision, M.H.; Project administration, M.H. All authors have read and agreed to the published version of the manuscript.

Funding: This research received no external funding.

Institutional Review Board Statement: Not applicable.

Informed Consent Statement: Not applicable.

Conflicts of Interest: The authors declare no conflict of interest.

\section{References}

1. Cameron, J.A.; Milner, D.J.; Lee, J.S.; Cheng, J.; Fang, N.X.; Jasiuk, I.M. Employing the biology of successful fracture repair to heal critical size bone defects. Curr. Top. Microbiol. Immunol. 2013, 367, 113-132. [CrossRef]

2. Wang, W.; Yeung, K.W.K. Bone grafts and biomaterials substitutes for bone defect repair: A review. Bioact. Mater. 2017, 2, 224-247. [CrossRef]

3. Griffin, K.S.; Davis, K.M.; McKinley, T.O.; Anglen, J.O.; Chu, T.-M.G.; Boerckel, J.D.; Kacena, M.A. Evolution of Bone grafting: Bone grafts and tissue engineering strategies for vascularized bone regeneration. Clin. Rev. Bone Miner. Metab. 2015, 13, 232-244. [CrossRef]

4. Pape, H.C.; Evans, A.; Kobbe, P. Autologous bone graft: Properties and techniques. J. Orthop. Trauma 2010, 24, S36-S40. [CrossRef]

5. Sen, M.K.; Miclau, T. Autologous iliac crest bone graft: Should it still be the gold standard for treating nonunions? Injury 2007, 38, S75-S80. [CrossRef]

6. Rouwkema, J.; Khademhosseini, A. Vascularization and Angiogenesis in tissue engineering: Beyond creating static networks. Trends Biotechnol. 2016, 34, 733-745. [CrossRef] 
7. Nguyen, L.H.; Annabi, N.; Nikkhah, M.; Bae, H.; Binan, L.; Park, S.; Kang, Y.; Yang, Y.; Khademhosseini, A. Vascularized bone tissue engineering: Approaches for potential improvement. Tissue Eng. Part B Rev. 2012, 18, 363-382. [CrossRef] [PubMed]

8. Rouwkema, J.; Rivron, N.C.; van Blitterswijk, C.A. Vascularization in tissue engineering. Trends Biotechnol. 2008, $26,434-441$. [CrossRef] [PubMed]

9. Stegen, S.; van Gastel, N.; Carmeliet, G. Bringing new life to damaged bone: The importance of angiogenesis in bone repair and regeneration. Bone 2015, 70, 19-27. [CrossRef] [PubMed]

10. Chang, H.; Knothe Tate, M.L. Concise review: The periosteum: Tapping into a reservoir of clinically useful progenitor cells. Stem Cells Transl. Med. 2012, 1, 480-491. [CrossRef] [PubMed]

11. Gruneboom, A.; Hawwari, I.; Weidner, D.; Culemann, S.; Muller, S.; Henneberg, S.; Brenzel, A.; Merz, S.; Bornemann, L.; Zec, K.; et al. A network of trans-cortical capillaries as mainstay for blood circulation in long bones. Nat. Metab. 2019, 1, 236-250. [CrossRef]

12. Herzog, D.P.; Dohle, E.; Bischoff, I.; Kirkpatrick, C.J. Cell communication in a coculture system consisting of outgrowth endothelial cells and primary osteoblasts. Biomed. Res. Int. 2014, 2014, 320123. [CrossRef]

13. Fuchs, S.; Hofmann, A.; Kirkpatrick, C.J. Microvessel-like structures from outgrowth endothelial cells from human peripheral blood in 2-dimensional and 3-dimensional co-cultures with osteoblastic lineage cells. Tissue Eng. 2007, 13, 2577-2588. [CrossRef] [PubMed]

14. Guillotin, B.; Bourget, C.; Remy-Zolgadri, M.; Bareille, R.; Fernandez, P.; Conrad, V.; Amedee-Vilamitjana, J. Human primary endothelial cells stimulate human osteoprogenitor cell differentiation. Cell. Physiol. Biochem. 2004, 14, 325-332. [CrossRef] [PubMed]

15. Dohle, E.; Fuchs, S.; Kolbe, M.; Hofmann, A.; Schmidt, H.; Kirkpatrick, C.J. Sonic hedgehog promotes angiogenesis and osteogenesis in a coculture system consisting of primary osteoblasts and outgrowth endothelial cells. Tissue Eng. Part A 2010, 16, 1235-1237. [CrossRef] [PubMed]

16. Villars, F.; Guillotin, B.; Amedee, T.; Dutoya, S.; Bordenave, L.; Bareille, R.; Amedee, J. Effect of HUVEC on human osteoprogenitor cell differentiation needs heterotypic gap junction communication. Am. J. Physiol.-Cell Physiol. 2002, 282, C775-C785. [CrossRef]

17. Simunovic, F.; Winninger, O.; Strassburg, S.; Koch, H.G.; Finkenzeller, G.; Stark, G.B.; Lampert, F.M. Increased differentiation and production of extracellular matrix components of primary human osteoblasts after cocultivation with endothelial cells: A quantitative proteomics approach. J. Cell. Biochem. 2019, 120, 396-404. [CrossRef]

18. Zhang, Y.; Schedle, A.; Matejka, M.; Rausch-Fan, X.; Andrukhov, O. The proliferation and differentiation of osteoblasts in co-culture with human umbilical vein endothelial cells: An improved analysis using fluorescence-activated cell sorting. Cell. Mol. Biol. Lett. 2010, 15, 517-529. [CrossRef]

19. Ma, B.; Li, M.; Fuchs, S.; Bischoff, I.; Hofmann, A.; Unger, R.E.; Kirkpatrick, C.J. Short-term hypoxia promotes vascularization in co-culture system consisting of primary human osteoblasts and outgrowth endothelial cells. J. Biomed. Mater. Res. A 2019. [CrossRef]

20. Barron, M.J.; Goldman, J.; Tsai, C.J.; Donahue, S.W. Perfusion flow enhances osteogenic gene expression and the infiltration of osteoblasts and endothelial cells into three-dimensional calcium phosphate scaffolds. Int. J. Biomater. 2012, 2012, 915620. [CrossRef]

21. Shui, C.X.; Scutt, A. Mild heat shock induces proliferation, alkaline phosphatase activity, and mineralization in human bone marrow stromal cells and Mg-63 cells in vitro. J. Bone Miner. Res. 2001, 16, 731-741. [CrossRef] [PubMed]

22. Patel, J.J.; Utting, J.C.; Key, M.L.; Orriss, I.R.; Taylor, S.E.; Whatling, P.; Arnett, T.R. Hypothermia inhibits osteoblast differentiation and bone formation but stimulates osteoclastogenesis. Exp. Cell Res. 2012, 318, 2237-2244. [CrossRef] [PubMed]

23. Yang, D.; Guo, S.; Zhang, T.; Li, H. Hypothermia attenuates ischemia/reperfusion-induced endothelial cell apoptosis via alterations in apoptotic pathways and JNK signaling. FEBS Lett. 2009, 583, 2500-2506. [CrossRef] [PubMed]

24. Sakaguchi, K.; Hinata, Y.; Kagawa, Y.; Iwasaki, K.; Tsuneda, S.; Shimizu, T.; Umezu, M. Low-temperature culturing improves survival rate of tissue-engineered cardiac cell sheets. Biochem. Biophys. Rep. 2018, 14, 89-97. [CrossRef]

25. Li, M.; Fuchs, S.; Bose, T.; Schmidt, H.; Hofmann, A.; Tonak, M.; Unger, R.; Kirkpatrick, C.J. Mild heat stress enhances angiogenesis in a co-culture system consisting of primary human osteoblasts and outgrowth endothelial cells. Tissue Eng. Part C Methods 2014, 20, 328-339. [CrossRef]

26. Lennon, D.P.; Haynesworth, S.E.; Young, R.G.; Dennis, J.E.; Caplan, A.I. A chemically defined medium supports in vitro proliferation and maintains the osteochondral potential of rat marrow-derived mesenchymal stem cells. Exp. Cell Res. 1995, 219, 211-222. [CrossRef]

27. Carpentier, G. ImageJ Contribution: Angiogenesis Analyzer. ImageJ News, 5 October 2012; p. 1.

28. Honda, M.; Aizawa, M. Preliminary Study for co-culture of osteoblasts and endothelial cells to construct the regenerative bone. Key Eng. Mater. 2017, 758, 269-272. [CrossRef]

29. Blair, H.C.; Larrouture, Q.C.; Li, Y.; Lin, H.; Beer-Stoltz, D.; Liu, L.; Tuan, R.S.; Robinson, L.J.; Schlesinger, P.H.; Nelson, D.J. Osteoblast differentiation and bone matrix formation in vivo and in vitro. Tissue Eng. Part B Rev. 2017, 23, 268-280. [CrossRef]

30. Kaneshiro, S.; Ebina, K.; Shi, K.; Higuchi, C.; Hirao, M.; Okamoto, M.; Koizumi, K.; Morimoto, T.; Yoshikawa, H.; Hashimoto, J. IL-6 negatively regulates osteoblast differentiation through the SHP2/MEK2 and SHP2/Akt2 pathways in vitro. J. Bone Miner. Metab. 2014, 32, 378-392. [CrossRef]

31. Hashida, Y.; Nakahama, K.; Shimizu, K.; Akiyama, M.; Harada, K.; Morita, I. Communication-dependent mineralization of osteoblasts via gap junctions. Bone 2014, 61, 19-26. [CrossRef]

32. Adams, R.H.; Alitalo, K. Molecular regulation of angiogenesis and lymphangiogenesis. Nat. Rev. Mol. Cell Biol. 2007, 8, 464-478. [CrossRef]

33. Folkman, J. Angiogenesis: An organizing principle for drug discovery? Nat. Rev. Drug Discov. 2007, 6, 273-286. [CrossRef] [PubMed] 
34. Thiel, A.; Reumann, M.K.; Boskey, A.; Wischmann, J.; von Eisenhart-Rothe, R.; Mayer-Kuckuk, P. Osteoblast migration in vertebrate bone. Biol. Rev. Camb. Philos. Soc. 2018, 93, 350-363. [CrossRef]

35. Ichida, M.; Yui, Y.; Yoshioka, K.; Tanaka, T.; Wakamatsu, T.; Yoshikawa, H.; Itoh, K. Changes in cell migration of mesenchymal cells during osteogenic differentiation. FEBS Lett. 2011, 585, 4018-4024. [CrossRef] [PubMed]

36. Koduru, S.V.; Leberfinger, A.N.; Pasic, D.; Forghani, A.; Lince, S.; Hayes, D.J.; Ozbolat, I.T.; Ravnic, D.J. Cellular based strategies for microvascular engineering. Stem Cell Rev. 2019, 15, 218-240. [CrossRef] [PubMed]

37. Madeddu, P. Therapeutic angiogenesis and vasculogenesis for tissue regeneration. Exp. Physiol. 2005, 90, 315-326. [CrossRef]

38. Kim, D.Y.; Kim, K.M.; Kim, E.J.; Jang, W.G. Hypothermia-induced RNA-binding motif protein 3 (RBM3) stimulates osteoblast differentiation via the ERK signaling pathway. Biochem. Biophys. Res. Commun. 2018, 498, 459-465. [CrossRef]

39. Aisha, M.D.; Nor-Ashikin, M.N.; Sharaniza, A.B.; Nawawi, H.M.; Kapitonova, M.Y.; Froemming, G.R. Short-term moderate hypothermia stimulates alkaline phosphatase activity and osteocalcin expression in osteoblasts by upregulating Runx2 and osterix in vitro. Exp. Cell Res. 2014, 326, 46-56. [CrossRef] [PubMed]

40. Zhu, X.; Buhrer, C.; Wellmann, S. Cold-inducible proteins CIRP and RBM3, a unique couple with activities far beyond the cold. Cell. Mol. Life Sci. 2016, 73, 3839-3859. [CrossRef] [PubMed]

41. Garrido, C.; Brunet, M.; Didelot, C.; Zermati, Y.; Schmitt, E.; Kroemer, G. Heat shock proteins 27 and 70: Anti-apoptotic proteins with tumorigenic properties. Cell Cycle 2006, 5, 2592-2601. [CrossRef]

42. Matz, J.M.; Blake, M.J.; Tatelman, H.M.; Lavoi, K.P.; Holbrook, N.J. Characterization and regulation of cold-induced heat shock protein expression in mouse brown adipose tissue. Am. J. Physiol. 1995, 269, R38-R47. [CrossRef]

43. Uchida, C.; Gee, E.; Ispanovic, E.; Haas, T.L. JNK as a positive regulator of angiogenic potential in endothelial cells. Cell Biol. Int. 2008, 32, 769-776. [CrossRef]

44. Guillotin, B.; Bareille, R.; Bourget, C.; Bordenave, L.; Amedee, J. Interaction between human umbilical vein endothelial cells and human osteoprogenitors triggers pleiotropic effect that may support osteoblastic function. Bone 2008, 42, 1080-1091. [CrossRef]

45. Lampert, F.M.; Simunovic, F.; Finkenzeller, G.; Pfeifer, D.; Stark, G.B.; Winninger, O.; Steiner, D. Transcriptomic changes in osteoblasts following endothelial cell-cocultivation suggest a role of extracellular matrix in cellular interaction. J. Cell. Biochem. 2016, 117, 1869-1879. [CrossRef]

46. Simunovic, F.; Steiner, D.; Pfeifer, D.; Stark, G.B.; Finkenzeller, G.; Lampert, F. Increased extracellular matrix and proangiogenic factor transcription in endothelial cells after cocultivation with primary human osteoblasts. J. Cell. Biochem. 2013, 114, 1584-1594. [CrossRef]

47. Kocherova, I.; Bryja, A.; Mozdziak, P.; Angelova Volponi, A.; Dyszkiewicz-Konwinska, M.; Piotrowska-Kempisty, H.; Antosik, P.; Bukowska, D.; Bruska, M.; Izycki, D.; et al. Human Umbilical Vein Endothelial Cells (HUVECs) Co-culture with osteogenic cells: From molecular communication to engineering prevascularised bone grafts. J. Clin. Med. 2019, 8, 1602. [CrossRef]

48. Clarkin, C.E.; Garonna, E.; Pitsillides, A.A.; Wheeler-Jones, C.P. Heterotypic contact reveals a COX-2-mediated suppression of osteoblast differentiation by endothelial cells: A negative modulatory role for prostanoids in VEGF-mediated cell: Cell communication? Exp. Cell Res. 2008, 314, 3152-3161. [CrossRef]

49. Clarkin, C.E.; Emery, R.J.; Pitsillides, A.A.; Wheeler-Jones, C.P. Evaluation of VEGF-mediated signaling in primary human cells reveals a paracrine action for VEGF in osteoblast-mediated crosstalk to endothelial cells. J. Cell. Physiol. 2008, 214, 537-544. [CrossRef] [PubMed]

50. Harrison, R.H.; St-Pierre, J.P.; Stevens, M.M. Tissue engineering and regenerative medicine: A year in review. Tissue Eng. Part B Rev. 2014, 20, 1-16. [CrossRef] [PubMed]

51. Matsuda, N.; Shimizu, T.; Yamato, M.; Okano, T. Tissue engineering based on cell sheet technology. Adv. Mater. 2007, 19, 3089-3099. [CrossRef] 